\title{
THE EFFECTS OF BASKETBALL AND SOCCER TRAINING ON ARTERIAL STIFFNESS
}

\author{
EFEITOS DO TREINAMENTO DE BASQUETEBOL EFUTEBOL SOBREA RIGIDEZ ARTERIAL
}

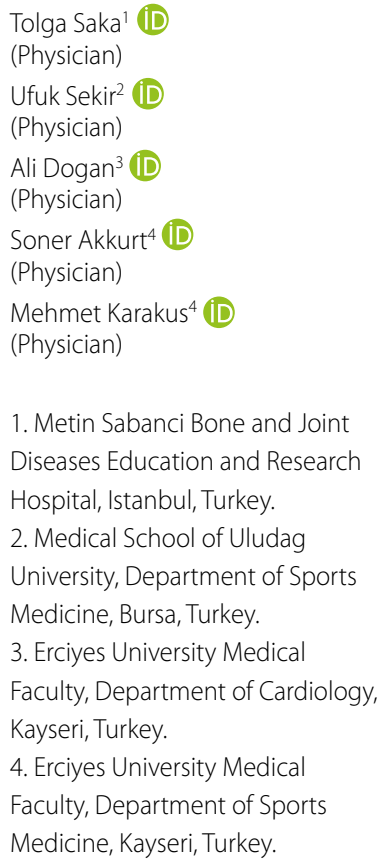

1. Metin Sabanci Bone and Joint Diseases Education and Research Hospital, Istanbul, Turkey. 2. Medical School of Uludag University, Department of Sports Medicine, Bursa, Turkey. 3. Erciyes University Medical Faculty, Department of Cardiology, Kayseri, Turkey.

4. Erciyes University Medical Faculty, Department of Sports Medicine, Kayseri, Turkey.

\section{Correspondence:}

Soner Akkurt. Erciyes University Medical Faculty, Department of Sports Medicine, Kayseri, Turkey, drsonerakkurt@hotmail.com

\begin{abstract}
Objective: The purpose of this study was to examine arterial stiffness in elite basketball and soccer athletes by pulse wave velocity. Methods: The cohort comprised 35 healthy male volunteers aged 17 to 26 years. All the subjects were either basketball players $(n=9)$, soccer players $(n=12)$ or sedentary controls $(n=14)$. Arterial stiffness was measured by the Pulse Trace System (Micro Medical Ltd., Rochester, UK) and echocardiographic images were taken using a commercially available machine (Vivid 7 GE-Vingmed, Horten, Norway) with a $2.5 \mathrm{MHz}$ transducer. Results: The basketball players had significantly higher heights and body weights as compared to both the soccer players and the controls. The aortic elastic properties derived from the echocardiographic measurements did not differ between the groups. The peripheral pulse wave velocity measurements showed significantly lower values both in the basketball and soccer players compared to the controls, whereas the central pulse wave velocity measurement was significantly lower only in the basketball players as compared to the controls. No significant difference was seen between the basketball and soccer players. Conclusions: The results of this study show that football and basketball exercises comprised of aerobic, anaerobic, endurance balance-coordination and sport-specific training play a role in reducing arterial stiffness. Level of evidence l; type of study: prognostic study.
\end{abstract}

Keywords: Vascular stiffness; Basketball; Soccer; Pulse wave velocity.

\section{RESUMO}

Objetivo: O propósito deste estudo foi examinar a rigidez arterial em atletas de basquetebol e futebol medindo a velocidade da onda do pulso. Métodos: A coorte foi composta por 35 voluntários saudáveis do sexo masculino, com idade entre 17 a 26 anos. Os participantes eram jogadores de basquetebol $(n=9)$, jogadores de futebol $(n=12)$ e controles sedentários ( $n=14$ ). A rigidez arterial foi medida com o Pulse Trace System (Micro Medical Ltd., Rochester, Reino Unido) e as imagens ecocardiográficas foram obtidas com um aparelho disponivel no mercado, com transdutor de 2,5 $\mathrm{MHz}$ (Vivid 7 GE-Vingmed, Horten, Noruega). Resultados: Os jogadores de basquetebol tinham estatura e peso corporal consideravelmente superiores aos dosjogadores de futebol e aos controles. As propriedades elásticas aórticas derivadas das medicas ecocardiográficas não diferiram entre os grupos. A velocidade da onda de pulso periférico foi significativamente menor nos jogadores de basquetebol e futebol em comparação com os controles, enquanto os jogadores de basquetebol tiveram velocidade da onda do pulso central consideravelmente menor que os controles. Não se observou diferença significativa entre os jogadores de basquetebol e os de futebol. Conclusões: Os resultados deste estudo mostram que os exercícios de treinamento de futebol e basquetebol: aeróbicos, anaeróbicos, de resistência, de coordenação e equilíbrio e os treinamentos especificos de cada esporte têm um papel importante na redução da rigidez arterial. Nível de Evidência l, Estudo prognóstico.

Descritores: Rigidez vascular; Basquetebol; Futebol; Análise de onda de pulso.

\section{RESUMEN}

Objetivo: El propósito de esteestudio fue examinar la rigidez arterial en atletas de básquetbol y fútbol midiendo la velocidad de onda de pulso. Métodos: La cohorte fue compuesta por 35 voluntarios saludables del sexo masculino, con edad entre $17 y$ 26 años. Los participantes eran jugadores de básquetbol ( $n=9)$, jugadores de fútbol $(n=12)$ y controles sedentarios $(n=14)$. La rigidez arterial fue medida con Pulse Trace System (Micro Medical Ltd., Rochester, Reino Unido) ylas imágenes ecocardiográficas fueron obtenidas con un aparato disponible en el mercado, con transductor de 2,5 MHz (Vivid $7 \mathrm{GE-Vingmed,} \mathrm{Horten,}$ Noruega). Resultados: Los jugadores de básquetbol tenían estatura y peso corporal considerablemente superiores a los de los jugadores de fútboly a los de los controles. Las propiedades elásticas aórticas derivadas de las medidas ecocardiográficas no difirieron entre los grupos. La velocidad de onda de pulso periférico fue significativamente menor en los jugadores de básquetbol y fútbol en comparación con los controles, mientras que los jugadores de básquetbol tuvieron velocidad de onda de pulso central considerablemente menor que los controles. No se observó diferencia significativa entre los jugadores de básquetbol y los de fútbol. Conclusiones: Los resultados de este estudio muestran que los ejercicios de entrenamiento de fútbol y básquetbol: aeróbicos, anaeróbicos, de resistencia, de coordinación y equilibrio y los entrenamientos específicos de cada deporte tienen un papel importante en la reducción de la rigidez arterial. Nivel de Evidencia I, Estudio pronóstico.

Descriptores: Rigidez vascular; Baloncesto; Fútbol; Análisis de la onda del pulso. 


\section{INTRODUCTION}

Diseases of the cardiovascular system (CVS) are one of the top causes of mortality everywhere in the world. Formation of atherosclerosis in the vessels can be genetic, environmental, nutrition/diet and exercise-related and it is known that atherosclerotic process in the vessels results in stiffness in the arterial vessels. ${ }^{1}$ Arterial stiffness measurements are used as an early indicator for asymptomatic atherosclerosis and CVS risk. ${ }^{2}$ Arterial pulse wave velocity (PWV) is widely used as a gold standard for the non-invasive assessment of arterial stiffness. Studies report that regular physical activity reduces stiffness, whereas a sedentary lifestyle increases stiffness. ${ }^{3}$ Several studies also provide evidence of reductions in central arterial stiffness with endurance training in both young and older populations and in competitive endurance athletes. ${ }^{4-8}$ Such results were noted from both cross-sectional and mostly longitudinal studies. ${ }^{4,7-12}$ Regular high-intensity swimming exercises reduce arterial stiffness, while marathon running increases arterial stiffness. ${ }^{13-15}$ Postmenopausal well trained runners/athletes and sedentary controls showed no difference in arterial stiffness. ${ }^{16}$ Nevertheless, Knez et al. reported lower central wave reflections in ultra-endurance competitive athletes. ${ }^{14}$ The purpose of this study was to examine the arterial stiffness of elite ball sports' athletes by pulse wave velocity.

\section{MATERIALS AND METHODS}

The cohort comprised 35 healthy male volunteers, ages 17 to 26 years (Table 1). All subjects were basketball players $(n=9)$, soccer players $(n=12)$ or sedentary controls $(n=14)$. All of them were non-obese (BMI $<30 \mathrm{~kg} / \mathrm{m}^{2}$ ), non-smoking, normotensive (< 140 / 80 mmHg), normolipidemic, and free of cardiovascular and other chronic diseases such as diabetes mellitus, chronic renal disease, peripheral arterial disease, alcohol addiction, history of vascular surgery, arrhythmia, cardiac valvulopathy or myocardial ischemia according to medical history, and clinical and electrocardiographic evaluation. None of the subjects was taking anti-diabetic or cardiovascular-acting medications and antioxidants or lipid-lowering supplements. Physical activity and nutrition habit was documented by questionnaire.

Subjects in group 1 (basketball players, $n=9$ ) were athletes undergoing training 15 hours per week for the last 12 months. The training was comprised of 6 hours of specific basketball training, 5 hours of aerobic / endurance activities, 2 hour of strength training, 1 hour of anaerobic dynamic training, and 1 hour of balance and coordination exercises. They have been playing for 6 years in average. Subjects in group 2 (soccer players, $\mathrm{n}$ $=12$ ) were athletes undergoing training 19 hours per week for the last 12 months. The training was comprised of 7 hours of specific soccer training, 7 hours of aerobic/endurance activities, 2 hours of strength training, 2 hours of anaerobic dynamic training, and 1 hour of balance and coordination exercises. They have been playing for 7 years in average. Subjects in group 3 were sedentary (less than 1 hour physical activity per week, $n=14$ ) and were matched with the other groups for age.

Table 1. Physical characteristics of athletes and controls. (Data are mean \pm SD).

\begin{tabular}{|c|c|c|c|}
\hline & $\begin{array}{c}\text { Basketball } \\
\text { players }(n=9)\end{array}$ & $\begin{array}{c}\text { Soccer players } \\
(n=12)\end{array}$ & $\begin{array}{l}\text { Controls } \\
(n=14)\end{array}$ \\
\hline Age (years) & $21.1 \pm 2.8$ & $21.2 \pm 2.3$ & $22.8 \pm 2.4$ \\
\hline Height (cm) & $191 \pm 8$ & $176 \pm 6^{* * *}$ & $174 \pm 5^{* * *}$ \\
\hline Weight $(\mathrm{kg})$ & $94.1 \pm 10.7$ & $69.9 \pm 6.8^{* * *}$ & $76.6 \pm 6.9^{* * *}$ \\
\hline Heart rate (beat.m-1) & $67 \pm 11$ & $71 \pm 9$ & $79 \pm 11^{*}$ \\
\hline Systolic blood pressure (mm.Hg) & $118 \pm 6$ & $113 \pm 9$ & $117 \pm 8$ \\
\hline Diastolic blood presssure (mm.Hg) & $80 \pm 3$ & $76 \pm 5$ & $78 \pm 8$ \\
\hline $\begin{array}{l}\text { Body fat percentage (\%) } \\
\mathrm{VO}_{2} \max \left(\mathrm{ml} \mathrm{kg}^{-1} \cdot \mathrm{min}^{-1}\right)\end{array}$ & $\begin{array}{c}18.8 \pm 3.0 \\
48.3 \pm 4.5^{*}\end{array}$ & $\begin{array}{c}18.3 \pm 2.5 \\
47.8 \pm 3.6^{*}\end{array}$ & $\begin{array}{l}19.2 \pm 3.4 \\
38.3 \pm 4.2\end{array}$ \\
\hline
\end{tabular}

Rev Bras Med Esporte - Vol. 27, № 1 - Jan/Mar, 2021
After being informed about the study and test procedures, and any possible risks and discomfort that might ensue, all subjects read and signed an informed-consent form approved by the University's Institutional Ethical Board for Protection of Human Subjects (number: 382), which also approved the study.

Upon arrival at the laboratory, measurements for body mass and body fat were taken from each subject. Body fat was calculated by measuring sub-dermal fat content from 5 body areas (abdomen, sub-scapulae, triceps, lateral side of the thigh and lateral side of the abdomen) using a skin-fold caliper and body mass was recorded using standard laboratory scales. 20 m shuttle test was used to obtain $\mathrm{VO}_{2}$ max values.

The Pulse Trace System (Micro Medical Ltd., Rochester, UK) was employed to record central and peripheral arterial stiffness. Pulse Trace PWV uses the standard Doppler method to detect the onset of flow in the artery. This equipment has a $4 \mathrm{MHz}$ Doppler probe for identifying the arrival of the arterial pulse. The transit time $(\Delta T)$ was computed from the foot-to-foot time difference in milliseconds between the two sequentially measured Doppler waveforms from the above mentioned locations using the 'R' wave of the ECG as a timing reference. The Pulse Trace PWV automatically detects the foot-to-foot of the waveform. The average of ten waveforms from each location is used and the SD is calculated and displayed. At each time point, the measurements were made three times for each individual subject and the mean value was recorded. For the measurements of central and peripheral arterial stiffness, the distance (D) between the carotid artery and brachial artery, and the distance between the carotid artery and femoral artery was measured using a measuring tape, respectively. PWV in $\mathrm{m} / \mathrm{sec}$ is automatically calculated by dividing the time delay by the externally measured distance between locations (PWV $=\mathrm{D} / \triangle \mathrm{T})$. All waveforms are displayed and the detected onset of the pulse is marked.

Images were obtained by a commercially available machine (Vivid $7 \mathrm{GE}-$ Vingmed, Horten, Norway) with a $2.5 \mathrm{MHz}$ transducer. All patients were examined at rest while in the left lateral recumbent position following the recommendations of the American Society of Echocardiography images were obtained in the parasternal long and short axis and in the apical four and five chamber views using two dimension and M-Mode Doppler. ${ }^{17}$ All of the measurements were digitized at the peak of the $\mathrm{R}$ wave by the average of 3 cardiac cycles. The ascending aorta was recorded in the two-dimensional guided M-Mode tracings. Aortic diameters were recorded $3 \mathrm{~cm}$ above the aortic valve. Aortic systolic diameter was determined at the time of the full opening of the aortic valve, and aortic diastolic diameter was determined at the peak of QRS. Blood pressure was measured simultaneously from the right brachial artery with an aneroid sphygmomanometer. Korotkoff phases I and $V$ of the measurements were used to determine the systolic and diastolic blood pressure.

1. Aortic strain (AS) was calculated as follows: ${ }^{18}$

$$
A S=(\text { AoS - AoD) / AoD. (AoS = systolic aortic diameter and }
$$$$
\text { AoD = diastolic aortic diameter) }
$$

2. Aortic distensibility (AD) was calculated as follows: ${ }^{18}$

$$
\begin{gathered}
A D=2 \times(A \circ S-A o D) /[A o D \times(S B P-D B P)] .(S B P=\text { systolic blood } \\
\text { pressure, } D B P=\text { diastolic blood pressure, AoS = systolic aortic } \\
\text { diameter and AoD = diastolic aortic diameter })
\end{gathered}
$$

3. Aortic stiffness index (beta stiffness index, BSI) was calculated as follows: ${ }^{18}$

$\mathrm{BSI}=\ln (\mathrm{SBP} / \mathrm{DBP}) /[(\mathrm{AoS}-\mathrm{AoD}) / \mathrm{AoD}]$. (SBP=systolic blood pressure and $\mathrm{DBP}=$ diastolic blood pressure)

Statistical analysis was performed using SPSS version 16.0 (SPSS, SPSS Inc, Chicago, Illinois, USA) software. For comparison among the 
groups, one-way analysis of variance (ANOVA) was used. Scheffe' post hoc test was performed to evaluate a significant F-value. All measurements are expressed as mean \pm SD. All tests were two-tailed and the level of significance was set at $p<0.05$.

\section{RESULTS}

Demographic and physical characteristics of the study groups are shown in Table 1. Basketball players had significantly higher height and body weight as compared to both soccer players and controls ( $p<0.001-0.05)$. Heart rate was significantly reduced in basketball players than only in the control group $(p<0.05)$. As indicated in Table 2, aortic elastic properties derived from echocardiographic measurements did not differ between the groups $(p<0.05)$. On the other hand peripheral pulse wave velocity measurements reflected significantly lower values both in the basketball $(p<0.001)$ and soccer players $(p<0.05)$ compared to controls, whereas central pulse wave velocity measurement was significantly lower only in basketball players $(p<0.05)$ as compared to controls (Table 3). No significant difference was seen between basketball and soccer players $(p>0.05)$.

Table 2. Aortic elastic properties in athletes and controls. (Data are mean \pm SD).

\begin{tabular}{|c|c|c|c|}
\hline & $\begin{array}{c}\text { Basketball } \\
\text { players }(n=9)\end{array}$ & $\begin{array}{c}\text { Soccer players } \\
(n=12)\end{array}$ & $\begin{array}{c}\text { Controls } \\
(n=14)\end{array}$ \\
\hline Systolic aortic diameter (cm) & $2.8 \pm 0.2$ & $2.8 \pm 0.4$ & $2.8 \pm 0.3$ \\
\hline Diastolic aortic diameter (cm) & $2.5 \pm 0.2$ & $2.5 \pm 0.4$ & $2.6 \pm 0.3$ \\
\hline Aortic distensibility $\left(\mathrm{mm} \cdot \mathrm{Hg}^{-1} \cdot 10^{-3}\right)$ & $5.38 \pm 2.1^{*}$ & $5.38 \pm 2.15^{*}$ & $4.51 \pm 3.15$ \\
\hline Aortic stiffness index & $4.24 \pm 1.29 * * *$ & $5.24 \pm 2.26^{*}$ & $6.71 \pm 3.75$ \\
\hline Aortic strain & $0.10 \pm 0.04$ & $0.11 \pm 0.04$ & $0.08 \pm 0.05$ \\
\hline
\end{tabular}

Table 3. Pulse wave velocity in athletes and controls. (Data are mean \pm SD).

\begin{tabular}{c|c|c|c}
\hline & $\begin{array}{c}\text { Basketball } \\
\text { players }(\mathbf{n = 9 )}\end{array}$ & $\begin{array}{c}\text { Soccer players } \\
(\mathbf{n}=\mathbf{1 2})\end{array}$ & $\begin{array}{c}\text { Controls } \\
(\mathbf{n}=\mathbf{1 4})\end{array}$ \\
\hline Carotid-brachial PWV & $5.80 \pm 0.84^{*}$ & $6.39 \pm 0.89$ & $6.89 \pm 0.86$ \\
\hline Carotid-femoral PWV & $5.76 \pm 0.68^{* * *}$ & $6.73 \pm 1.49^{*}$ & $7.89 \pm 0.56$ \\
\hline
\end{tabular}

${ }^{*} p<0.05,{ }^{* * *} p<0.001$. PWV=Pulse wave velocity

\section{DISCUSSION}

In our study aortic elasticity measured by echocardiography did not differ between the groups and were similar to many studies in literature. A study found an inverse relationship between increased aerobic performance capacity $\left(\mathrm{VO}_{2}\right.$ max $)$ and central arterial stiffness even in sedentary individuals. ${ }^{19}$ The same study found that elderly individuals who performed endurance exercise had lower central arterial stiffness compared to more sedentary young individuals. ${ }^{9}$ Otsuki et al. showed that central pulse wave velocity was lower in individuals with longer athletic/sports history (average 8 years) compared to those with shorter athletic history (average 5 years) in their study investigating the effect of short and long term sports activities on central arterial stiffness in short and long distance runners. ${ }^{19}$ Kakiyama et al. stated that aerobic exercise performed at $70 \% \mathrm{VO}_{2}$ max level for at least 60 minutes 3 - 4 days and 8 weeks duration cycling ergometry significantly reduced central PWV in young sedentary male subjects. ${ }^{5}$ In week 4 after the end of training (detraining effects) all these improvements were reversed which was why the authors underlined the need for continued exercise training. ${ }^{5}$ Currie et al. reported a 9\% significant decrease in central pwv with an intensive endurance exercise composed of upper arm ergometer performed for as short as 6 days but at $65 \% \mathrm{VO}_{2}$ max for 2 hours throughout 6 days (from $5.9 \mathrm{~m} / \mathrm{sec}$ down to $5.4 \mathrm{~m} / \mathrm{sec}$ ). ${ }^{20}$ Hayashi at al. also showed that walking and jogging exercises performed at medium intensity $(75 \%$ of heart rate reserve) for 16 weeks 2-3 days a week 45 minutes each day might significantly reduce central PWV in middle-aged sedentary individuals. ${ }^{21}$ A recent meta-analysis summarizing the effect of regular aerobic or endurance exercise and a combination of both on central arterial stiffness proved the positive effects of aerobic exercise. ${ }^{22,23}$

Both meta-analyses included studies that had investigated the effects of exercise on sedentary subjects. Huang et al. detected in a meta-analysis a $0.47 \mathrm{~m} / \mathrm{sec}$ lower central PWV compared to controls following physical activity of medium intensity comprising walking and cycling exercises performed for 40 - $60 \mathrm{~min} /$ day, 3 - 5 days/week for 2 - 12 months by sedentary healthy or chronically diseased individuals. ${ }^{23}$ Investigators underlined that aerobic exercise of longer duration would increase the effect according to the analysis results. In a meta-analysis Li at al. showed that a medium to high intensity walking and cycling exercise performed for 12 - 16 weeks, 3 days/week and 30 - 40 minutes/day significantly decreased central pwv (6.7 - 7.5\%) in healthy sedentary individuals. ${ }^{22}$ The analysis found a reduced pwv in both young (7.0\%) and middle-advanced aged (6.7\%) groups. Higher exercise intensity was associated with better pwv. In studies with athlete populations Nualmin et al. showed that arterial stiffness was lower in athletes who had been swimming and running 4 - 5 days/week for 9 years in average compared to sedentary individuals..$^{13}$ Knez et al. reported a lower central wave reflection in athletes that performed ultra endurance training 16 hours a week in average compared to less active athletes (who exercised 1 hour a week in average). ${ }^{14}$ In one of the very few studies with football players in literature Cioni et al. found a lower central pwv in soccer players with a play history of 4 years in average $(5.87 \mathrm{~m} /$ sec) compared to the sedentary control group $(6.62 \mathrm{~m} / \mathrm{sec}) .{ }^{24}$ They stated that elite soccer players had better central arterial stiffness. Again in one of the very few studies with basketball players in literature Ratgeber et al. did not find any difference in central pwv between 11 and 16 years young basketball players ( $5.82 \mathrm{~m} / \mathrm{sec}$ ) and age adjusted sedentary controls (5.83 $\mathrm{m} / \mathrm{sec}){ }^{25}$ The authors discussed that the young aortic wall was very elastic and increased blood pressure would not cause any stiffness of the aortic wall. Similarly, in our study basketball players who exercised regularly 15 hours in average per week for one year had lower central arterial stiffness values compared to sedentary controls. Soccer players who exercised 18 hours in average per week for one year had even lower arterial stiffness values although the difference was not significant. Long-term basketball training affects the carotid artery hemodynamically and stiffness drops during both rest and basketball training compared to sedentary controls. ${ }^{26}$

Contrary to many studies showing a positive effect of aerobic exercise on central PWV the effect of the latter on peripheral PWV has been controversial. ${ }^{21}$ Hayashi et al. did not observe any significant difference in peripheral PWV with medium intensity (75\% of heart rate reserve) walking and jogging exercises of 45 minutes for 2-3 days per week in middle aged sedentary individuals. ${ }^{21}$ According to these results investigators suggested that it would be difficult to bring about a significant change of peripheral arterial stiffness with aerobic exercise. Notwithstanding Schmidt-Trucksaess et al. indicated that femoral arterial diameter and compliance in endurance trained males such as cyclists, short-distance runners and triathletes who had trained for 30 hours per week in average for at least 14 years were significantly larger than those in age-matched sedentary counterparts. ${ }^{27}$ In a recent meta-analysis on the effect of combined aerobic and resistance training versus regular aerobic training on peripheral arterial stiffness the benefit of aerobic exercise was proven. ${ }^{28}$ Montero et al. examined the carotid femoral PWV in a meta-analysis about the effect of aerobic exercise which we took as peripheral arterial stiffness in our study. ${ }^{28}$ The subjects of the studies included in the meta-analysis were generally sedentary healthy or chronically ill who performed medium intensity walking and cycling exercises of 30-40 minutes per day 2-3 days per week for 8-26 weeks. Aerobic exercised reduced their pwv $0.52 \mathrm{~m} / \mathrm{sec}$ more than the 
control counterparts. The same meta-analysis did not show any additional benefit of combined endurance and aerobic training versus only aerobic exercise. In a study with marathon runners who trained 15 hours per week for 12 years in average $(6.89 \mathrm{~m} / \mathrm{sec})$ carotid femoral PWV was interestingly found to be higher compared to their sedentary counterparts $(6.33 \mathrm{~m} /$ sec)..$^{15}$ Investigators stated that aerobic exercise had a U-shaped effect on arterial stiffness and might be harmful after a certain level although exercise was generally beneficial. In our study peripheral arterial stiffness measured as PWV was found to be significantly lower in soccer $(6.73 \mathrm{~m}$ / sec) and basketball players (5.76 m / sn) compared to their sedentary controls $(7.89 \mathrm{~m} / \mathrm{sec}){ }^{15}$ These results indicate that ball sports might benefit peripheral arterial stiffness.

How regular aerobic exercise affects arterial compliance is not known for certain. It would not be accurate to single out a mechanism of action. Most probably the two responsible mechanisms of action are sympathetic tonus reduction through aerobic exercise and increased endothelium-dependent vasodilation associated with improved endothelial function. ${ }^{29-33}$ Endothelial cells in the veins play an important role in regulating vascular activity by releasing endothelin-1 (ET-1) and nitric oxide. Endurance exercise reduces the plasma concentration of ET-1 which is a potent vasoconstrictor peptide and increases the concentration of nitric oxide which is an endothelium derived relaxation factor. ${ }^{34-39}$ Thus the smooth muscles of the veins relax. Nitric oxide is reported to play an important role in buffering the arterial system by increased arterial stiffness caused by inhibition of nitric oxide synthase..$^{40-42}$ In light of recent studies and the present study it is possible to state that aerobic exercise potentially reduces central arterial stiffness.

All authors declare no potential conflict of interest related to this article

AUTHORS' CONTRIBUTIONS: Each author made significant individual contributions to this manuscript. SA - Design, literature search, writing; TS - Design, concept, design, materials, writing; US - Data collection, processing, interpretation; AD - Literature search, analysis, interpretation; MK - Processing, data collection, analysis.

\section{REFERENCES}

1. Green DJ, Maiorana A, O'Driscoll G, Taylor R. Effect of exercise training on endothelium-derived nitric oxide function in humans. J Physiol. 2004;561(Pt 1):1-25.

2. Safar ME, London GM. Therapeutic studies and arterial stiffness in hypertension: recommendations of the European Society of Hypertension. The Clinical Committee of Arterial Structure and Function. J Hypertens. 2000;18(11):1527-35.

3. Horta BL, Schaan BD, Bielemann RM, Vianna CA, Gigante DP, Barros FC, et al. Objectively measured physical activity and sedentary-time are associated with arterial stiffness in Brazilian young adults. Atherosclerosis. 2015;243(1):148-54

4. Cameron J, Dart A. Exercise training increases total systemic arterial compliance in humans. Am J Physiol. 1994;26(2 Pt 2):693-701.

5. Kakiyama T, Sugawara J, Murakami H, Maeda S, Kuno S, Matsuda M. Effects of short-term endurance training on aortic distensibility in young males. Med Sci Sports Exerc. 2005;37(2):267-71.

6. Collier SR, Kanaley JA, Carhart RJ, Frechette V, Tobin MM, Hall AK, et al. Effect of 4 weeks of aerobic or resistance exercise training on arterial stiffness, blood flow and blood pressure in pre- and stage-1 hypertensives. J Hum Hypertens. 2008;22(10):678-86.

7. Tanaka H, Dinenno FA, Monahan KD, Clevenger CM, DeSouza CA, Seals DR. Aging, habitual exercise, and dynamic arterial compliance. Circulation. 2000;102(11):1270-5.

8. Edwards DG, Lang JT. Augmentation index and systolic load are lower in competitive endurance athletes. Am J Hypertens. 2005;18(5 Pt 1):679-83.

9. Vaitkevicius PV, Fleg JL, Engel JH, O'Connor FC, Wright JG, Lakatta LE, et al. Effects of age and aerobic capacity on arterial stiffness in healthy adults. Circulation. 1993:88(4 Pt 1):1456-62.

10. Kingwell BA, Cameron JD, Gillies KJ, Jennings GL, Dart AM. Arterial compliance may influence baroreflex function in athletes and hypertensives. Am J Physiol. 1995;268(1 Pt 2):411-8.

11. Monahan KD, Tanaka H, Dinenno FA, Seals DR. Central arterial compliance is associated with age and habitual exercise-related differences in cardiovagal baroreflex sensitivity. Circulation. 2001;104(14):1627-32.

12. Edwards DG, Schofield RS, Magyari PM, Nichols WW, Braith RW. Effect of exercise training on central aortic pressure wave reflection in coronary artery disease. Am J Hypertens. 2004;17(6):540-3.

13. Nualnim N, Barnes JN, Tarumi T, Renzi CP, Tanaka H. Comparison of Central Artery Elasticity in Swimmers, Runners, and the Sedentary. Am J Cardiol. 2011;107(5):783-7.

14. Knez WL, Sharman JE, Jenkins DG, Coombes JS. Central hemodynamics in Ultra-endurance athletes. J Sci Med Sport. 2008;11(4):390-5.

15. Vlachopoulos C, Kardara D, Anastasakis A, Baou K, Terentes-Printzios D, Tousoulis D, et al. Arterial Stiffness and Wave Reflections in Marathon Runners. Am J Hypertens. 2010;23(9):974-9.

16. Tanaka $\mathrm{H}$, DeSouza CA, Seals DR. Abe of age-related increase in central arterial stiffness in physically active women. Arterioscler Thromb Vasc Biol. 1998:18(1):127-32.

17. Lang RM, Bierig M, Devereux RB, Flachskampf FA, Foster E, Pellikka PA, et al. Recommendations for Chamber Quantification: A report from the American Society of Echocardiography's Guidelines and Standards Committee and the Chamber Quantification Writing Group, Developed in Conjunction with the European Association of Echocardiography, a Branch of the European Society of Cardiology. J Am Soc Echocardiogr. 2005;18(12):1440-63.

18. Stefanadis C, Stratos C, Boudoulas H, Kourouklis C, Toutouzas P. Distensibility of the ascending aorta: comparison of invasive and non-invasive techniques in healthy men and in men with coronary artery disease. Eur Heart J. 1990;11(11):990-6.

19. Otsuki T, Maeda S, lemitsu M, Saito Y, Tanimura Y, Ajisaka R, et al. Relationship between arterial stiffness and athletic training programs in young adult men. Am J Hypertens. 2007;20(9):967-73

20. Currie KD, Thomas SG, Goodman JM. Effects of short-term endurance exercise training on vascular function in young males. Eur J Appl Physiol. 2009;107(2):211-8.

21. Koichiro Hayashi K, Sugawara J, Komine H, Maeda S, Yokoi T. Effects of Aerobic Exercise Training on the Stiffness of Central and Peripheral Arteries in Middle-Aged Sedentary Men. Jpn J Physiol. 2005;55(4):235-9.
22. LiY, Hanssen H, Cordes M, Rossmeissl A, Endes S, Schmidt-Trucksaess A. Aerobic, resistance and combined exercise training on arterial stiffness in normotensive and hypertensive adults: A review. Eur J Sport Sci. 2015;15(5):443-57.

23. Huang C, Wang J, Deng S, She Q, Wu L. The effects of aerobic endurance exercise on pulse wave velocity and intima media thickness in adults: A systematic review and meta-analysis. Scand J Med Sci Sports. 2016;26(5):478-87.

24. Cioni G, Berni A, Gensini GF, Abbate R, Boddi M. Impaired Femoral Vascular Compliance and Endothelia Dysfunction in 30 Healthy Male Soccer Players: Competitive Sports and Local Detrimental Effects. Sports Health. 2015;7(4):335-40

25. Ratgeber L, Lenkey Z, Nemeth A, Hidvegi E, Husznai R, Verzar Z, et al. The effect of physical exercise on arterial stiffness parameters in young sportsmen. Acta Cardiol. 2015;70(1):59-65.

26. Liu HB, Yuan WX, Qin KR, Hou J. Acute effect of cycling intervention on carotid arterial hemodynamics: basketball athletes versus sedentary controls. Biomed Eng Online. 2015;14(Suppl 1):S17.

27. Schmidt-Trucksaess A, Schmid A, Brunner C, Scherer N, Zaech G, Keul J, et al. Arterial proper-ties of the carotid and femoral artery in endurance- trained and paraplegic subjects. J Appl Physiol. 2000;89(5):1956-63.

28. Montero D, Vinet A, Roberts CK. Effect of combined aerobic and resistance training versus aerobic training on arterial stiffness. Int J Cardiol. 2015;178:69-76.

29. Hautala AJ, Maekikallio TH, Kiviniemi A, Laukkanen RT, Nissilae S, Huikuri HV, et al. Heart rate dynamics after controlled training followed by a home-based exercise program. Eur J Appl Physiol. 2004;92(3):289-97.

30. Melanson EL, Freedson PS. The effect of endurance training on resting heart rate variability in sedentary adult males. Eur J Appl Physiol. 2001;85(5):442-9.

31. Boutouyrie P, Lacolley P, Girerd X, Beck L, Safar M, Laurent S. Sympathetic activation decreases mediumsized arterial compliance in humans. Am J Physiol. 1994;267(4 Pt 2):1368-76.

32. DeSouza CA, Shapiro LF, Clevenger CM, Dinenno FA, Monahan KD, Tanaka H, et al. Regular aerobic exercise prevents and restores age-related declines in endothelium-dependent vasodilation in healthy men. Circulation. 2000;102(12):1351-7.

33. Martin WH, Kohrt WM, Malley MT, Korte E, Stoltz S. Exercise training enhances leg vasodilatory capacity of 65-yr-old men and women. J Appl Physiol. 1990;69(5):1804-9.

34. Maeda S, Miyauchi T, Kakiyama T, Sugawara J, lemitsu M, Irukayama-Tomobe Y, et al. Effects of exercise training of 8 weeks and detraining on plasma levels of endothelium-derived factors, endothelin- 1 and nitric oxide, in healthy young humans. Life Sci. 2001;69(9):1005-16.

35. Maeda S, Tanabe T, Miyauchi T, Otsuki T, Sugawara J, lemitsu M, et al. Aerobic exercise training reduces plasma endothelin-1 concentration in older women. J Appl Physiol. 2003;95(1):336-41.

36. Maeda S, Tanabe T, Otsuki T, Sugawara J, lemitsu M, Miyauchi T, et al. Moderate regular exercise increases basal production of nitric oxide in elderly women. Hypertens Res. 2004;27(12):947-53.

37. Kingwell BA, Sherrard B, Jennings GL, Dart AM. Four weeks of cycle training increases basal production of nitric oxide from the forearm. Am J Physiol. 1997;272(3 Pt 2):H1070-7.

38. Higashi Y, Sasaki S, Kurisu S, Yoshimizu A, Sasaki N, Matsuura H, et al. Regular aerobic exercise augments endothelium-dependent vascular relaxation in normotensive as well as hypertensive subjects: role of endothelium-derived nitric oxide. Circulation 1999;100(11):1194-202.

39. Goto C, Higashi Y, Kimura M, Noma K, Hara K, Nakagawa K, et al. Effect of different intensities of exercise on endothelium-dependent vasodilation in humans: role of endothelium-dependent nitric oxide and oxidative stress. Circulation. 2003;108(5):530-5

40. Wilkinson IB, Qasem A, McEniery CM, Webb DJ, Avolio AP, Cockcroft JR. Nitric oxide regulates local arterial distensibility in vivo. Circulation. 2002;105(2):213-7.

41. Wilkinson IB, MacCallum H, Cockcroft JR, Webb DJ. Inhibition of basal nitric oxide synthesis increases aortic augmentation index and pulse wave velocity in vivo. Br J Clin Pharmacol. 2002;53(2):189-92.

42. Kinlay S, Creager MA, Fukumoto M, Hikita H, Fang JC, Selwyn AP, et al. Endothelium-derived nitric oxide regulates arterial elasticity in human arteries in vivo. Hypertension. 2001;38(5):1049-53. 